\title{
French risk assessment body faces uncertain future
}

Paris. The future of a commission set up by the French government to provide independent assessments of the risks associated with technology may be under threat, warned its chairman, Jean-Jacques Salomon, last week.

The so-called Collège de la Prévention des Risques Technologiques (CPRT), which was created in 1989 by the socialist prime minister, Michel Rocard, is attached to the office of the prime minister. Its 12 members are appointed by the president of the republic for six-year terms, and a third of the membership is renewed every two years.

The CPRT has two important powers. Although it produces 'opinions' at the request of the government, it can also do so on its own initiative. Second, the commission can make public its recommendations. It has published more than a dozen such opinions on industries such as nuclear power, chemicals and petroleum, and new technologies such as biotechnology.

But a rumour that the CPRT is to be abolished is now circulating. One reason is that the government is trying to save money - and the CPRT is perceived by some as an irritant. Moreover, although the independence of the commission is widely acknowledged, some in the conservative government are suspicious of a creation of the former socialist administration.

Circumstantial evidence of the govern- ment's lack of interest comes from its failure to appoint a successor to Salomon, who resigned as chairman last year to concentrate on his work at the Conservatoire National des Arts et Métiers in Paris.

Salomon, who has continued as acting chairman of CPRT, admits that it is "heads or tails" that the CPRT will be abolished. The government's "temptation" to abolish the CPRT is being tempered, he says, by concern that such a move could further harm the reputation of a government that is already mistrusted by the public. "We will see in 1996 if there is provision made in the budget [for CPRT]."

The CPRT, which has an annual budget of just FF1.5 million (US $\$ 300,000$ ), is particularly vulnerable because it has no permanent staff. Another weakness that has compromised its effectiveness is that while in theory it has unlimited powers of investigation, in practice, there is no legal obligation on anybody to reply to its questions.

Nevertheless, Salomon argues that the abolition of CPRT would mean the loss of "an independent voice which calls for vigilance against technocrats". Indeed, it is widely acknowledged that France lacks the counterbalances to the power of government and industry that are common, for example, in the United States.

Declan Butler

\section{Political uncertainty delays EMBL decision}

Munich. A vote on plans to increase the budget of the Heidelberg-based European Molecular Biology Laboratory (EMBL) by six per cent over the next three years has been left open until mid-February

because France was unable to make a decision at last month's EMBL council meeting.

All the other 14 member states have approved the budget increase which Kafatos: still hoping would be provided

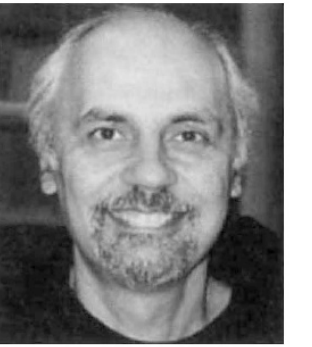

almost entirely by Germany, whose contributions to EMBL and the European Laboratory for Particle Physics (CERN) rise this year to take into account its increased economic weight following reunification. Member state contributions are broadly based on gross domestic product.

But France, caught between a recent reorganization of its research ministry (see Nature 378,225 ; 1995) and general political uncertainty, is unable to confirm that it would be able to support the small increase in its own contribution that would be demanded by the proposed budget.

EMBL is under considerable financial pressure as it tries to realize new scientific goals, already approved by council, set by its director Fotis Kafatos who took office nearly two years ago. These include the establishment of a new major programme in developmental biology at the main laboratory in Heidelberg, and expansion of two outstations, the European Bioinformatics Institute at Hinxton, near Cambridge, and the Grenoble outstation concerned with structural biology.

Plans also include an expanded visitors programme and the establishment of four EMBL research groups at a new centre for genetics at Monterotondo, near Rome, where the EU-sponsored mouse gene repository is to be sited.

Even if the budget is approved next month, Kafatos will still be faced with the prospect of achieving these ambitions on a level of funding that will barely keep up with inflation. But he remains optimistic: "everyone in Europe is facing financial hardship", he says, "and we will do our part".

Alison Abbott

\section{Natural History Museum joins Kew for lottery cash}

London. The Royal Botanic Gardens at Kew and the Natural History Museum in London have secured substantial funds from the proceeds of Britain's National Lottery for two major projects.

The museum has been awarded $£ 6$ million (US $\$ 9$ million) by the National Lottery Heritage Fund towards its $£ 12$-million scheme to transform the former Geological Museum into a three-floor Earth sciences museum (see Nature 378, 2; 1995).

Kew Gardens, meanwhile, has won £21 million (US\$39 million) from the Millennium fund - set aside from lottery income for projects marking the beginning of the next century - for the Millennium Seed Bank, which will be built near Wakehurst Place in West Sussex, the site of Kew's existing facility. The new institution is expected to conserve at least 10 per cent of the world's flora by the year 2010 .

Phase one of the Earth sciences gallery at the Natural History Museum is due to open in July this year. Three further exhibitions, part of phase two and three, are expected to open in the summer of 1998.

\section{EC encourages science for profit}

Munich. The European Commission has published a green paper (discussion document) on innovation intended to encourage greater European competitiveness in converting scientific performance into profitability.

An initiative of the research commissioner, Edith Cresson, and the commissioners for industrial affairs and energy, the paper points to the low level of investment in research and development in Europe (2 per cent of gross national product) compared to Japan (2.7 per cent) and the United States (2.7 per cent), the slow and expensive procedures of patenting, and extensive bureaucracy as the main contributors to Europe's relative lack of innovation.

It calls for comments from scientists, industry and investors on 13 proposals for corrective action, which include the orientation of research at national and European levels towards applications, more programmes to encourage mobility of researchers, increased support for venture capital and tax benefits to encourage investment in research.

The commission is to consider producing a white paper (policy document) to be presented to the European Parliament and the Council of Ministers, based on the green paper and taking into account comments received during this year.

Alison Abbott 